\title{
ボイラ過熱器管寿命評価のための複層合成灰腐食試験法
}

\author{
斉藤 喜 久*, 庄子哲 雄** \\ * 東北電力株式会社総合研究所 \\ ** 東北大学工学部基礎工学教室
}

\section{High Temperature Corrosion Test Method in Simulated Oil Fired Boiler Environment for Survice Life Evaluation of Boiler S/H Tubes}

\author{
Yoshihisa Saito* and Tetsuo Shoji* \\ *General Research and Development Center, Tohoku Electric Power Company. \\ * Department of Engineering Science, Faculty of Engineering, Tohoku University
}

\begin{abstract}
In order to evaluate the survice life of supper heater tubes of oil fired boiler, a new high temperature corrosion test technique was developed where specimens were surrounded by double layer corrosives. Inner layer is $85 \% \mathrm{~V}_{2} \mathrm{O}_{5}+10 \% \mathrm{Na}_{2} \mathrm{SO}_{4}+5 \% \mathrm{Fe}_{2} \mathrm{O}_{3}$ (melted once at $900^{\circ} \mathrm{C}$ to form compounds with low melting point such as $\mathrm{Na}_{2} \mathrm{O} \cdot \mathrm{V}_{2} \mathrm{O}_{4} \cdot 5 \mathrm{~V}_{2} \mathrm{O}_{5}$ and $\mathrm{NaO} \cdot \mathrm{V}_{2} \mathrm{O}_{4}$ and clushed to powder) corrosive and outer $10 \% \mathrm{~V}_{2} \mathrm{O}_{5}+85 \% \mathrm{Na}_{2} \mathrm{SO}_{4}+5 \% \mathrm{Fe}_{2} \mathrm{O}_{3}$ corrosive, simulating the situation commonly observed on the $\mathrm{S} / \mathrm{H}$ tubes extracted from the actual boiler. This test environment reproduced local concentration of $\mathrm{Ni}$ and $\mathrm{S}$ at the interface between scale and metal as commonly observed on damaged tubes during survice operation. Corrosion resistance of some $\mathrm{S} / \mathrm{H}$ tube materials are examined using this newly developed test technique. Furthermore, the effects of rare earth metal addition to $316 \mathrm{HTB}$ stainless steel named as 316-X on high temperature corrosion rate was examined by this technique. Results obtained showed that the 347 s.s. has higher resistance than 316 and 321 s.s. and also the addition of rare earth metal to 316 s.s. markedly improved the corrosion resistance. Some future problems which have to be solved for life prediction of boiler $\mathrm{S} / \mathrm{H}$ tubes are discussed.
\end{abstract}

\section{1. 緒 言}

蒸気温度 $569^{\circ} \mathrm{C}$, 圧力 $169 \mathrm{~kg} / \mathrm{cm}^{2}$ 級の発電ボイラ過 熱器管の高温部には通常 SUS 321, 316 ステンレス鋼管 が採用されている。これら鋼種は耐酸化性, クリープ特 性の優れた材料であるが，重油燃焼ボイラでは主として 次のよらな障害が起こっている。

（1）高温腐食減肉による管強度低下，（2) 水蒸気酸 化スケール剝離堆積による管路閉塞，（3)長時間使用に ともなら材質の劣化，実際にはこれらが複合して管噴破 などの障害にいたると考えられている。

本報告では過熱器管の信頼性確保の立場から管強度に 影響を及ぼす $(1)$ に注目して，高温腐食試験法とそれに

* T980 仙台市中山七丁目 2 番 1 号 (2-1, Nakayama 7-chome, Sendai, 980 Japan)

** 厂980 仙台市荒巻字青葉 (Aoba, Aramaki, Sendai, 980 Japan)
もとづく耐食性の改善について述べたものである。

周知のように, 火力発電用重油ボイラの過熱器ステン レス鋼管の高温腐食機構については 1940 年代より多く の研究がなされてきたが，近年ではアルカリ硫酸塩によ る硫化/酸化モデルが有力な機構と考えられている1)。

しかし, 雾囲気や付着物が複雑なため統一的な理論は 確立されるに至っていない。実際のボイラで 36,500 時 間使用した過熱器管の減肉状況は Fig. 1 に示すように アバタ状の溝食が平均 $1.5 \mathrm{~mm}$ の深さに達している。 また，顕著な腐食を示さない場合でも長期間使用中には Fig. 2 (a) のようにガス側表面に微細な割れを生じ，そ のさ裂内部は Fig. 2 (b) に示すよらなS の侵入が見ら れ管強度に著しい影響を与えていることが推察される。

このように，高温高王下で腐食環境におかれている過 熱器管は上述の諸要因によって設計寿命よりも短い使用 時間で取替えられる場合が多く, 高温腐食とクリープき 


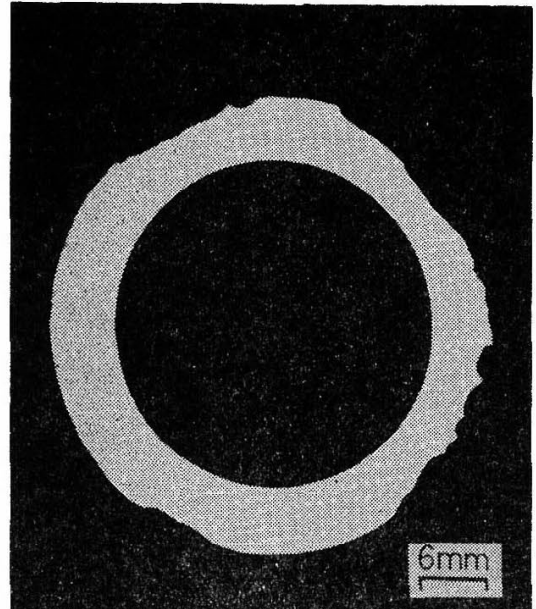

Fig. 1 Perpendicular cross section of penetrated tube (SUS316HTB, 36500 hrs serviced).

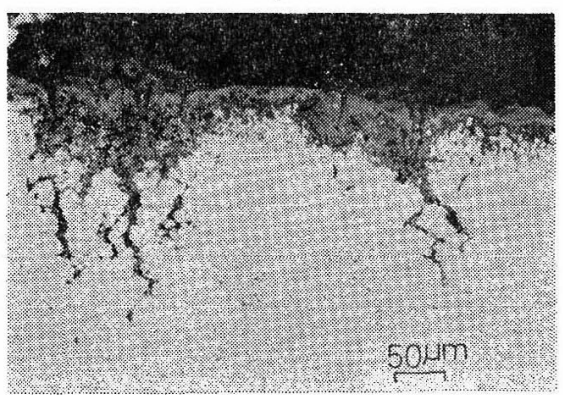

(a) Optical photograph of branched cracks

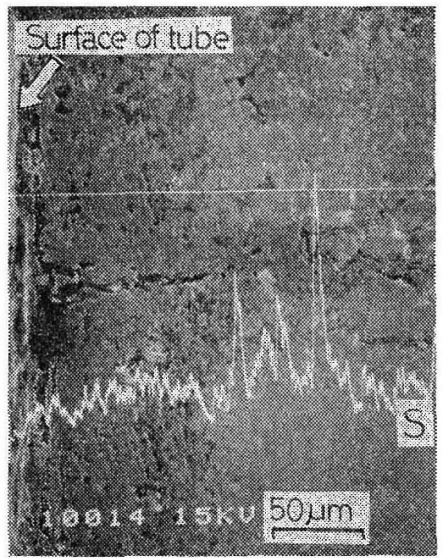

(b) EPMA analysis of sulfur at crack

Fig. 2 A example of crack appeared in boiler $\mathrm{S} / \mathrm{H}$ tube serviced for $140,000 \mathrm{hrs}$.

裂進展の重畳, 経年的材質劣化としての浸炭, 析出相, 熱 疲労あるいは溶接割れなど環境脆化そ考慮した寿命評価 法の確立が要望されている。本報文でほ実際のボイラ使 用条件下に括ける過熱器管材の寿命評価のたる半円状溝 を有する円筒の強度を有限变形解析で評価し，腐食潅の 管強度に及ぼす影響を明らかにした。また，耐食性の向 上は管寿命に藷しい效果をるたらすことは既に明らかに

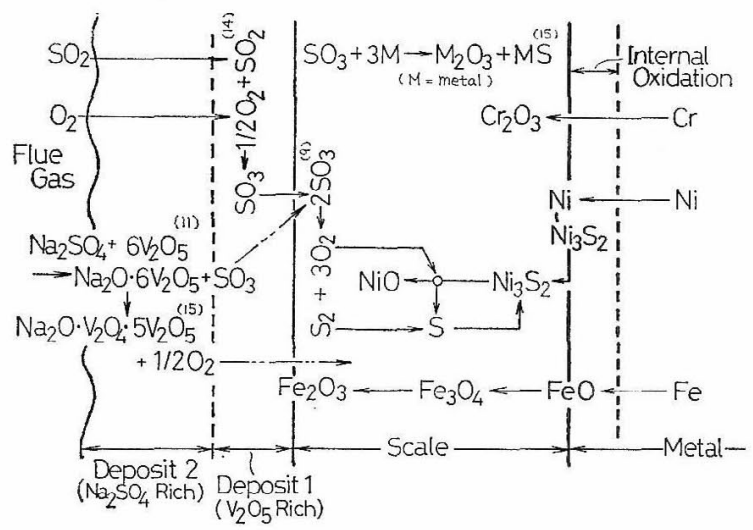

Fig. 3 Hot corrosion processes including oxidation and sulfidation under double layer deposites.

されている22ので，研究過程で解析した Fig. 3 の高温

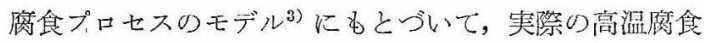
現象を再現する手法として複酋合成灰試験法を提案する とともに，Fig. 3 のプロセスを考虑して希土類元素々 微量添加した SUS 316 X 鋼る試作し耐食性およびクリ ープ特性が改善されること壳明らかにしたものである。

\section{2. 高温腐食による管強度低下の有限変形解析}

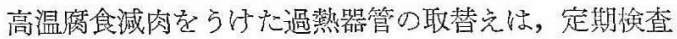
期間を利用して外観検查あるいは，外径测定によって減 肉量を军測し，基準を超觉たものを対象に行われている のが現状であるが，減肉以局所的であるので，応力分乎 は均一でなく，平均外径による肉厚計算は妥当ではな い。木節では，外壁が管軸方向に半円溝状に侵食され た, 内正をらける円管の応力解析を行い, 管の力学的举 動について検討した結果を示す。

Hibbitt ら゙により示された平面ひずみ状態における Lagrange 表示による弾塑性有限変形堌分理論に基つい た有限要素解析プログラム ${ }^{5}$ を用い，内生 $P$ を受ける円 管 (SUS 316 HTB) の2 次元応力解析を行う。実際に観 察された腐食蔳の形状を円孔切欠さでモデル化し，团欠 き深さ $\boldsymbol{R}$ 汸 $1.6,2.8,4.0 \mathrm{~mm}$ の3 通りの場合につい て計算を実施する。

円管の温度は渦熱器管において測定された上限の温度 $620^{\circ} \mathrm{C}$ である。応力ーひずみ曲線は文献尚の Hot Tensile のデータを基に，Ramberg-Osgood 型構成法則により 高ひずみみで桩張し，その結果を 4 本の直線で示した。 縦弾性係数，ポアンン比，および降伏応力は乞れぞれ， $E=1.47 \times 10^{4} \mathrm{~kg} / \mathrm{mm}^{2}, \nu=0.34, \sigma_{Y}=12.4 \mathrm{~kg} / \mathrm{mm}^{2}$ であ る。

$R=1.6,2.8$ および $4.0 \mathrm{~mm}$ の切欠きを有する円管の 四角形要素数はそ杂尔れ，202，199，202であり，節点数 


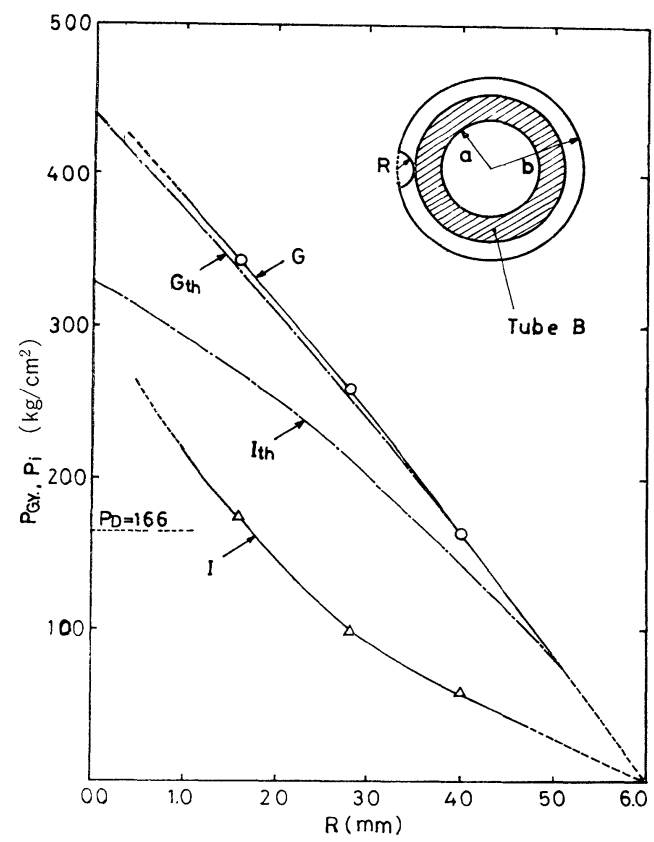

Fig. 4 Effects of semi-circular notch depth on internal pressure at general yielding and notch tip yielding.

は 245，242，244 である。

内圧 $P$ の増加に伴って外壁の半円切欠き底より塑性 域が現われ, 対数らせんの形で拡がり, 全断面降伏(G.Y.) 時には，切欠き底から $45^{\circ}$ の方向に材料が塑性して内 壁とつながる。この傾向はすべての切欠き深さのものに 共通であった。

切欠き深さ $R$ によらず管の変形は G. Y. 以後急激に大

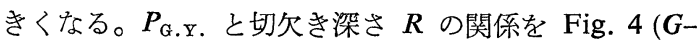
曲線) に示す。 $G_{t h}$ 一曲線は図中に斜線で示したリガメン 卜の肉厚を持つ円管 $\mathrm{B}$ が全断面降伏するときの内圧

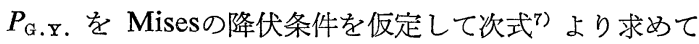
得た曲線である。

$$
P_{\mathrm{G} . \mathrm{Y} .}=\frac{2}{\sqrt{3}} \sigma_{Y} \ln \frac{b-R}{a}
$$

半円状濉の深さだケ, 外壁が一様に減肉した円管として, 上式より全断面降伏内圧を見積ることは妥当である。

Fig. 4 には切欠さ底に塑性域が発生する時の内圧 $P_{i}$ と $R$ の関係を同時に示してある (I-曲線)。さらに円管 $\mathrm{B}$ に塑性域が発生する時の内压 $P_{i}$ と $R$ の関係を次式7) より求め (Mises 材に対して) $I_{\mathrm{th}}$-曲線で示す。

$$
P_{i}=\left\{1-\left(\frac{a}{b-R}\right)^{2}\right\} \frac{\sigma_{Y}}{\sqrt{3}}
$$

$I$ 一曲線と $I_{\mathrm{th}}$ 一曲線の違いは切欠き底の応力集中によるも のであり，切欠き底に拈ける塑性域の発生は，その後の クリープに大きな影響を及ぼすであろらことを考えれ ば，切欠きの存在を考慮した $I$-曲線による評価が最も

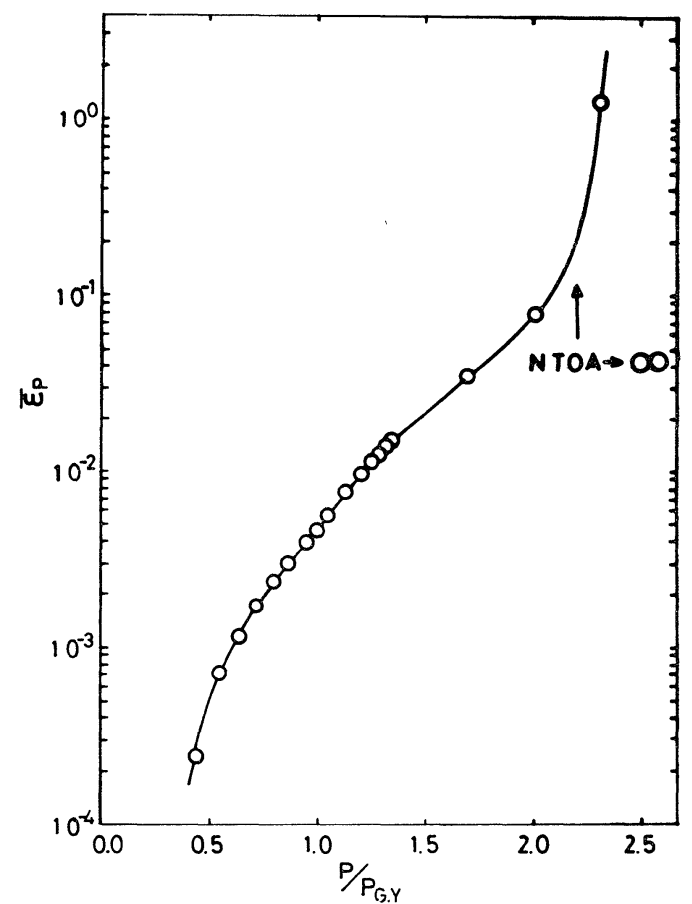

Fig. 5 Relationship between notch tip plastic strain and internal pressure, and occurence of bulge deformation at NTOA $\rightarrow \infty$.

適切であろう。ちなみに定常圧力 $\left(169 \mathrm{~kg} / \mathrm{cm}^{2}\right)$ におい て, 半円切欠き底から塑性域が発生する限界半円半径は $1.7 \mathrm{~mm}$ 程度であり,この程度の溝腐食があると定常内 圧のみで，切欠き底で塑性が生じてしまう。

ボイラ過熱器管の外壁が溝状に腐食され, 蒸気俚によ り膨張し最終的に噴破に至る現象は, 腐食溝の底が内圧 によって局部的に大変形を受けることによるものである と考えられる。切欠き底の变形に注目し，切欠き底先端 の開口角 NTOA の内压増加に伴ら変化を調べてみると 全断面降伏以後 NTOA が急増し，P/P.Y. 2.2 亿扣い て NTOA が無限に大きくなり切欠き底が突出（バルジ 変形）しはじめることがわかる。切欠き底が突出した時 点で負荷段階に拈ける $\bar{\varepsilon}_{P}$ の分布は, それ以前の負荷段 階に括ける分布と異なり切欠き先端で急増する。この現 象により，切欠き底が突出する時点をるって内圧により 管が受ける負荷形態が大さく恋化することがわかる。切 欠き底先端の要素に和ける $\bar{\varepsilon}_{P}$ の内圧による变化を Fig. 5 に示す。切欠き底が突出しはじめると同時に $\bar{\varepsilon}_{P}$ が急 激に増大し, $P / P_{\mathrm{G} . \mathrm{x} .}$ 2.2 に打いてほぼ $100 \%$ にも達 する。

\section{3. 寿命評価のための複層合成灰腐食試験法の提案}

過熱器管の寿命評価に際しては実際のボイラ使用状況 を模擬した高温腐食試験により適切な腐食速度を求める 
ことが重要である。高温腐食は管付着物の性状が重要な 因子をなすが，ひと頃のような高バナジウムの付着物は 少なく, 近年では多量のアルカリ硫酸塩を含むものが多 い。したがって，バナジウム・アタックによる加速酸化 理論では説明できずアルカリ硫酸塩腐食と解釈されてい る。この腐食系は一般に次の反応式(8)で示される。

$$
\begin{gathered}
\mathrm{Na}_{2} \mathrm{SO}_{4}+3 R \longrightarrow \mathrm{Na}_{2} \mathrm{O}+3 R_{2} \mathrm{O}+\mathrm{S} \\
\mathrm{M}+\mathrm{S} \longrightarrow \mathrm{MS} \\
\mathrm{Na}_{2} \mathrm{SO}_{4}+3 \mathrm{MS} \longrightarrow \mathrm{Na}_{2} \mathrm{O}+3 \mathrm{MO}+4 \mathrm{~S} \\
\text { こに, } \mathrm{R}: \text { 金属元素, 未燃炭素など還元剤 } \\
\mathrm{M}: \text { 金属元素 }
\end{gathered}
$$

筆者らのEPMAによる腐食管調査では管材/スケール 界面に硫化物の偏析を確認し, 熱化学平衡解析から Ni 硫化物であると結論 ${ }^{3)}$ した。この腐食プロセスは Fig. 3 に模式的に示したように, スケール/付着物界面に V$\mathrm{Fe}-\mathrm{S}$ 酸化物層 (Deposit 1) が存在する特徵がある。さ らに, 付着物 (Deposit 2) の主成分は $\mathrm{Na}_{2} \mathrm{SO}_{4}$ で残分 (約 14 wt\%) は Deposit 1 および燃焼ガスとの界面に偏 析する $\mathrm{Na}_{5} \mathrm{~V}_{12} \mathrm{O}_{32}, \mathrm{Na}_{2} \mathrm{~V}_{6} \mathrm{O}_{16}$ などであることを $\mathrm{X}$ 線回 折で確認した。また，腐食管の侵食溝の経路は重力方向 と一致し，管壁メタル温度 $620 \sim 630^{\circ} \mathrm{C}^{10)}$ を考慮すると Deposit 1/Deposit 2 界面近傍はダル状に溶融したバナ ジン酸塩であると考えられる。バナジン酸塩の腐食作用 については既に多くの研究 ${ }^{11), 12)}$ が報告されて拉り， $\mathrm{SO}_{3}$ 及び $\mathrm{O}_{2}$ の供給体として知られているが Deposit 1 層 の触媒作用も無視できない。

上記の調查解析と管材/スケール界面に $\mathrm{Na}, \mathrm{V}$ が検出 されない事実は $\mathrm{Na}_{2} \mathrm{SO}_{4}$ 及びバナジン酸塩が腐食に直接 関与するものでないことを示唆している。

すなわち, アルカリ硫酸塩腐食は付着物中の $\mathrm{Na}_{2} \mathrm{SO}_{4} /$ $\mathrm{V}_{2} \mathrm{O}_{5}$ の構成比率によらず， $\mathrm{V}_{2} \mathrm{O}_{5}$ の内方偏析飞依存す るものであり, Deposit 1/Deposit 2 界面近傍のバナジ ン酸塩から $\mathrm{SO}_{3}, \mathrm{O}_{2}$ を遊離することとあいまって，外 方から侵入してくる $\mathrm{SO}_{2}, \mathrm{O}_{2}$ を Deposit 1 層の触媒作 用で活性 $\mathrm{SO}_{3}$ とし，これら $\mathrm{SO}_{3}$ はさらにスケール層 で還元されて $\mathrm{O}_{2}$ 及び $\mathrm{S}_{2}$ を放出して気体/固体反応で 腐食を促進する ${ }^{13)}$ 。

ここで, アルカリ硫酸塩腐食がバナジウム・アタック と本質的に異なる点は $\mathrm{Na}_{2} \mathrm{SO}_{4}$ を主成分とする付着物 の存在下に和けるスケール/管材界面の $\mathrm{O}_{2}$ 分圧の低下 と，それに伴う $\mathrm{S}_{2}$ 分圧の上昇が $\mathrm{Ni}$ を優先的に硫化す る3)ことである。

以上の解析結果から実機を模擬した高温腐食試験方法 としては (1) $630^{\circ} \mathrm{C}$ 程度の融点を持つ $\mathrm{V}$ 化合物を腐食 郕とする，(2)硫化ポテンジャルを高めるための被覆剤 $\left(\mathrm{Na}_{2} \mathrm{SO}_{4}\right.$ 系) による埋没，（3）実機燃焼ガス条件に近似
した温度，䨌囲気の設定が重要である。

これら必要条件を考虑して採用した試験方法は次の通 りである。

(1) 腐食剤: 特級試薬で調整した $85 \% \mathrm{~V}_{2} \mathrm{O}_{5}+$ $10 \% \mathrm{Na}_{2} \mathrm{SO}_{4}+5 \% \mathrm{Fe}_{2} \mathrm{O}_{3}$ 混合物を電気炉で $900^{\circ} \mathrm{C}$ に 1 時間保持し, 放冷後ミルで粉砕した。この腐食剤の $\mathrm{X}$ 線 回折結果は主として $\mathrm{Na}_{2} \mathrm{O}, \mathrm{V}_{2} \mathrm{O}_{4}, 5 \mathrm{~V}_{2} \mathrm{O}_{5}\left(\mathrm{mt} 625^{\circ} \mathrm{C}\right)$ で あった。

(2) 被覆剤: 同じ試薬で10\% $\mathrm{V}_{2} \mathrm{O}_{5}+85 \% \mathrm{Na}_{2} \mathrm{SO}_{4}+$ $5 \% \mathrm{Fe}_{2} \mathrm{O}_{3}$ に調整, 混合した。この構成比率は実機の付 着物の平均組成に等しい。

(3) 試験片: $20 \times 25 \times 2^{t} \mathrm{~mm}$ に切り出し $0 / 2$ エメリ 一まで研磨後, アセトンで脱脂洗浄した。

（4）腐食剤の塗布：学振法 ${ }^{16)}$ 亿準じて特級アセトン で腐食剤を懸濁し塗布量 $20 \mathrm{mg} / \mathrm{cm}^{2}$ で両面に塗布し た。

（5）被覆剤による埋没：腐食剤を塗布した試験片は 灰分測定用角形 10 号磁性皿に入れて腐食剂重量の約 10 倍の被覆剤で埋没した。

（6）䨌囲気，温度: 実機の燃焼ガス組成に近似した $0.1 \% \mathrm{SO}_{2}+1 \% \mathrm{O}_{2}+14 \% \mathrm{CO}_{2}+\mathrm{N}_{2}$ 標準混合ガスを 10 $\mathrm{m} l / \mathrm{min}$ 流量で石英反応管中に流し, 温度は $650^{\circ} \mathrm{C}$ と した。

この方法で得られた結果を Fig. 6 亿示す。この場合， 比較のためにバナジウム・アタック法及び同法のガス雾 囲気の試験結果も併記してある。図でバナジゥム・アタ ック法によるものは直線則に従っているが上記方法のも のは二段対数則を示し長時間側で加速されている。雾囲 気は同じでも被覆しない場合は腐食速度は小さいことが 明らかである。一方, 各試験片の断面を EPMA 分析し

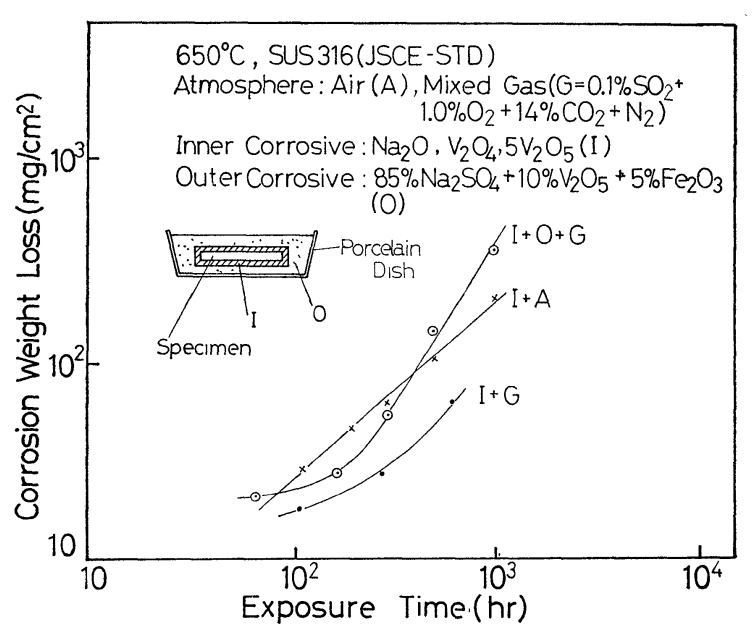

Fig. 6 Effects of test method on high temperature corrosion kinetics. 


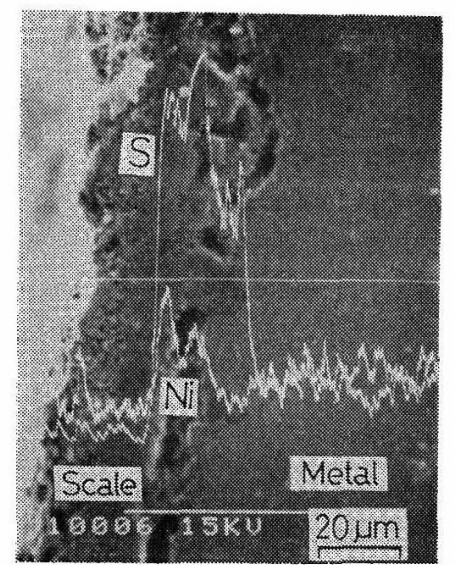

(a) Test specimen $\left(650^{\circ} \mathrm{C} \times 1,000 \mathrm{hrs}\right)$

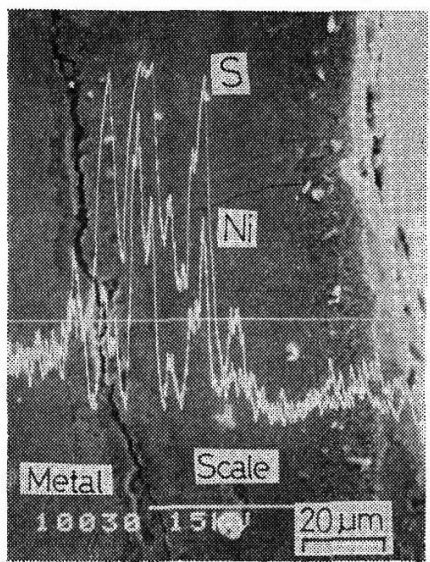

(b) Actual Boiler $\mathrm{S} / \mathrm{H}$ tube $(35,000 \mathrm{hrs})$

Fig. 7 Comparison of sulfidation of $\mathrm{Ni}$ between simulated environment and actual boiler environment.

た結果，本法にのみ金属/スケール界面に $\mathrm{Ni}, \mathrm{S} の$ 偏析 が認められその様子を Fig. 7 に示した。同図 (b) の実 際の過熱器管腐食スケールと比較すると, 本誌は年機の 腐食挙動をよく再現しているものと考劣てよく，さらに 長時問側の腐食挙動も本法によって明らかになるものと 期待される。

\section{4. 複層合成灰腐食試験法による各種過熱器管材及び 改良型 316:X 材の耐食性評価}

一般に耐食性を高める合金として $\mathrm{Cr}$ が添加されるが 発電ボイラにあっては現在の 18-8 系スデンレス鋼より 高級な耐食性高合金鋼はコスト的に問題があり採用され ていない。また，クロムメッキなど表面処理1や二重 管 ${ }^{17)}$ にって耐食性を改善する試みもなされているが耐 久性や経済性に疑問があり寒用化されていない。

そこで，管材自身に保護被膜修復機能を持たせること をねらってクリープ特性は優れているが耐食性の低い SUS 316 HTB 鋼に Ce を添加し耐食性の改善を試みた。 元来，希土類元素の酸化物，硫化物は $\mathrm{Ni}, \mathrm{Cr}$ に比心 て大きい負の生成自由エネルギーを持っており，極めて 安定しているので硫化, 酸化雲团気で優先的に硫化, 酸化 される。また，希土類元素の酸化，硫化物は高融点（例 えぼ $\mathrm{Ce}_{2} \mathrm{O}_{3}: 1625^{\circ} \mathrm{C}$ ) のものが多く内部金属の拡散を阻 止し耐食性を向上させることが知られている に，耐硫化性に及ぼす希土類元素の效果としては（1） $\mathrm{Cr}_{2} \mathrm{O}_{3}$ の密着性の改善，(2) 内部酸化物の形成促進，(3) $\mathrm{Cr}_{2} \mathrm{O}_{3}$ 成長速度の向上，といったことが報告 ${ }^{18)}$ れて利 り耐食性の改善が期待できる。

筆者らは希土類元素の中でも比較的入手容易な $\mathrm{Ce}$ を 選び，真空溶解した SUS 316 HTB の溶湯に Ce (pure) を $20 \sim 1300 \mathrm{ppm}$ の範囲で添加し，無添加材子含めて 5 種の合金を鋳造し，圧惩比約 33\% の供試材とした。た 掠，本材の固溶体化処理は $1050^{\circ} \mathrm{C} \times 30$ 分でその後水冷 した。この供試材の化学組成を市販の SUS 316 HTB と ともに Table 1 に示す。これら供試材の附食性を明らか にするため，第 3 章で提案した䄍層合成曱試険法にもと びいて高温腐食試験を行った。

その結果, 添加濃度 $20 \mathrm{ppm}$ までは效果は現われない が，それ以上 $1300 \mathrm{ppm}$ までは添加濃度の增加につれて 耐食性の改善が見られた。その一例として $50 \mathrm{ppm}$ 添加 材の結果を SUS 316 X と表示し実用鋼管の試験結果と ともに Fig. 8 に示した。図では明らかなように 500 時 間における腐食速度は SUS 316 X の母材である SUS

Table 1 Chemical compositions of materials used in this experiment.

\begin{tabular}{|c|c|c|c|c|c|c|c|c|c|c|}
\hline \multirow[b]{2}{*}{ Element } & \multirow[b]{2}{*}{$\mathrm{C}$} & \multirow[b]{2}{*}{$\mathrm{Si}$} & \multirow[b]{2}{*}{$\mathrm{Mn}$} & \multirow[b]{2}{*}{$P$} & \multirow[b]{2}{*}{ S } & \multirow[b]{2}{*}{$\mathrm{Ni}$} & \multirow[b]{2}{*}{$\mathrm{Cr}$} & \multicolumn{3}{|c|}{ (WT\%) } \\
\hline & & & & & & & & Mo & $\begin{array}{c}\text { Ce } \\
\text { checked }\end{array}$ & $\begin{array}{l}\text { Ce: } \\
\text { addition }\end{array}$ \\
\hline $316 \times A$ & 0.06 & 0.49 & 1.45 & 0.006 & 0.007 & 12.94 & 18.08 & 2.27 & $<0.001$ & 0.001 \\
\hline $316 \times B$ & 0.06 & 0.49 & 1.45 & 0.005 & 0.008 & 12.95 & 17.99 & 2.23 & 0.002 & 0.005 \\
\hline $316 \times C$ & 0.07 & 0,48 & 1.41 & 0.005 & 0.007 & 12.41 & 17.97 & 2.21 & 0.005 & 0.025 \\
\hline $316 \times D$ & 0.08 & 0.48 & 1.44 & 0.006 & 0.004 & 12.02 & 17.93 & 2.20 & 0.130 & 0.125 \\
\hline SUS 316 & 0.05 & 0.49 & 1.64 & 0.023 & 0.007 & 13.21 & 16.19 & 2.30 & -- & -- \\
\hline
\end{tabular}

HTB 


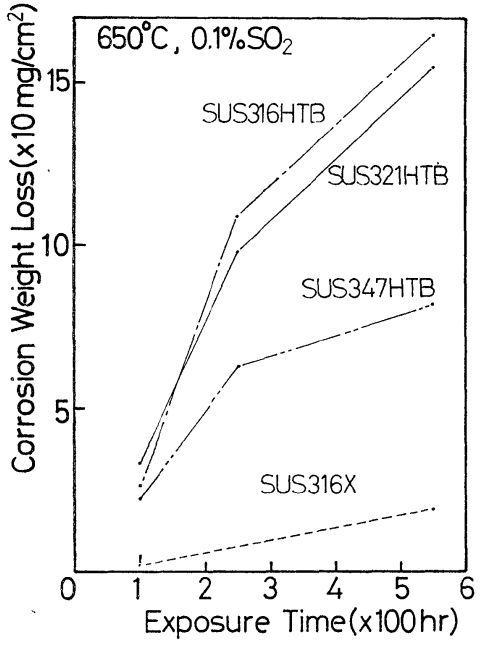

Fig. 8 Corrosion weight loss of some $\mathrm{S} / \mathrm{H}$ tube materials and improved $316 \mathrm{X}$ s.s. under simulated oil fired boiler environment.

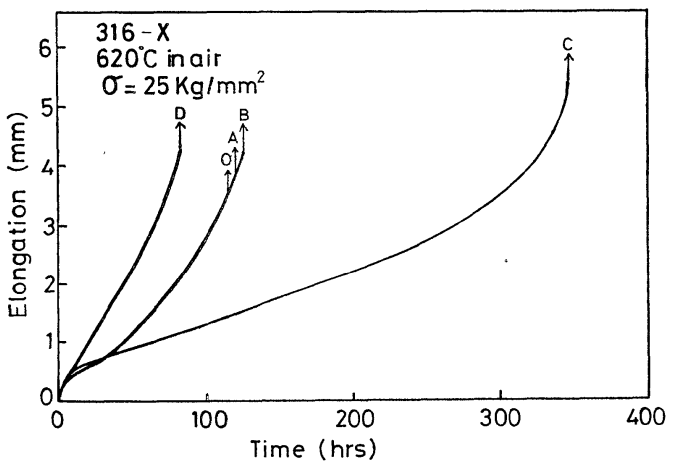

Fig. 9 Effect of $\mathrm{Ce}$ content on creep rupture time at $\sigma=25 \mathrm{~kg} / \mathrm{mm}^{2}\left(620^{\circ} \mathrm{C}\right)$.

316 HTB の約 $1 / 8$ に，優れた耐食性鋼管として普及し つつある SUS 347 HTB の約 1/4 に減少し改善されて いる。

このように耐食性の改善は認められたが，それに伴う クリープ特性を確認して扔く必要があり以下にその結果 について述べる。

クリープ試験は有効断面積 $9 \mathrm{~mm}^{2}$ の小型引張試験片 で, 温度 $620^{\circ} \mathrm{C}$, 応力 $25 \mathrm{~kg} / \mathrm{mm}^{2}$ の条件とし, 破断ま での伸びと時間を計測した。Fig. 9 は得られた結果で ある。

図中の記号 $\mathrm{O}, \mathrm{A}, \mathrm{B}, \mathrm{C}$ および D は各々 $\mathrm{Ce}$ 添加濃 度 $0,10,20,50,1300 \mathrm{ppm}$ の材料である。Ce の添加 効果は A, B では認められないが $\mathrm{C}$ では約 3 倍の破断 強さを示した。しかし D は A， B 及び O より短い時 間で破断した。

以上の試験結果から，適量の $\mathrm{Ce}$ を添加すると耐食
性, クリープ強度ともに改善する効果を示すが，Ce は 酸素とイオウとの親和力が大きいうえ，炭素とも大きな 親和力を有するため過度の添加は固溶体強化元素である 炭素を $\mathrm{Ce}$ の囲りに引き寄せるため強度低下となって現 われることも考光られる。な括，各添加材の組織検査护 よび介在物検査の結果からは特段の差違は認められなか った。したがって，Ce 添加に際しては十分な注意が必 要である。

\section{5. 過熱器管の寿命評価における今後の問題点}

以上 2 章 4 章に执いて，高温腐食による局部的な減 肉がある場合の管の静的強度低下を明らかし，さらに実 ボイラに拈いて生じている高温腐食の機構に基づいた新 しい複層合成灰高温腐食試験法を提案し，その試験法の 妥当性について述べてきた。合せて同試駼法によって耐 食性向上のための希土類元素添加効果について検討を加 え，その有効性を明らかにした。重油専焼ボイラに拉け る過熱器管の寿命評価においては, 高温腐食減肉速度の 見積りが極めて重要であることが指摘されているが2)， 上述の試験法はあくまであ加速試験法であるので，実条 件下に括ける腐食速度との対応を明らかにすることが必 要である。この場合特に留意すべき点は，材質の経年劣 化をどのように考慮に入れるかである。比較的短時間の 加速試験においては，材質劣化までる含めたデータを得 ることは困難であり，実条件下で劣化をうけた材料につ いての腐食試験データの蓄積が肝要である。

本稿では全く触れなかったが，クリープ強度の経年劣 化, 異材継手部に批る熱疲労さらには, 管内面スケール の問題など，過熱器管の寿命評価には，さらに多くの因 子に対する配慮が必要であるが，それぞれの損傷機構に 照し合せて適切な評価試験掞よび対策を施すことによ り，ボイラ過熱器管の信頼性をさらに向上させることが 可能であり，寿命の改善につながることが期待される。 今後，ますますボイラ高効率化などによって過熱器管の 管壁温度の上昇が予測され寿命評価のための基礎的なデ 一タの蓄積が望まれる。またそのことは，管寿命改善の ための適切な指針を与えることにもなろう。

\section{6. まとめ}

重油燃焼ボイラの過熱器ステンレス管外表面に発生す る高温腐食は管寿命やボイラの信頼性に多大な影響を与 えている。本報告は有限変形解析によって管強度低下の 挙動を究明し，管寿命や耐食性評価化必要な高温腐食試 験法および Ce 添加による耐食性の改善について検討し た。結果は次のとおりである。

（1）腐食溝を切欠きと見なした場合の凷欠き底にお ける塑性域の発生は，その後のクリープに大きな影響を 
及汭すであろうことを考えれば切欠きの存在を考慮した $\boldsymbol{I}$ 曲線による評価が最も適切であろう。

（2）腐食管付着物の層状偏析を模擬した複層合成灰 による高温腐食試験の結果は実材の腐食挙動をよく再現 し，長時間側の耐食性試験手法として有効と考えられ る。

（3）Ceを $50 \mathrm{ppm}$ 添加した SUS $316 \mathrm{X}$ は耐食性, クリープ強度に著しい効果を示したが, 過剩な添加はク リープ強度の低下をもたらすので注意が必要である。

\section{謝 辞}

本研究の遂行にあたり多大の御助言を睗った豊田工業 大学鈴木正彦教授ならびに東北大学高橋秀明教授に感謝 の意を表します。また，熱心な協力を得た鈴木克彦氏 (東北電力) 並びに橋田俊之氏 (東北大 [院]) に感謝しま す。な拉，本研究で用いた $\mathrm{Ce}$ 添加 $316 \mathrm{X}$ 鋼は大同特 殊鋼 (株) 研究開発本部管理部部長荒川昭夫氏ならびに 関係各位のご厚意によって試作されたものであり，ここ に付記して感謝いします。

$$
\text { (Received December 1, 1981) }
$$

$$
\text { 文献 }
$$

原田良夫：防食技術，26，No. 8, 471 (1977).

2) 庄子哲雄, 斉藤喜久, 高橋秀明, 鈴木正彦: 防食 技術, 31，196-201 (1982).
3) Y. Saito \& T. Shoji: IIW. Doc. No. IX-10779, (1979).

4) H. D. Hibbitt et al.: Int J. Solids. Struct. 6, 1069 (1970).

5) 双他 3 名; 機講論, No. 800-1, 16 (1980).

6) ASME Boiler \& Pressure Vessel Code, Sect III, Case Interpretation, 1592-7 (1975).

7) 竹山寿夫：初等塑性力学 (丸善).

8) E. L. Simons, G. V. Browning \& H. A. Liebhafsky: Corrosion, 11, No. 12, 505 (1955).

9) 化学大辞典, No. 3, (共立出版), (1963).

10）電力中央研究所報告: No. 275513 , No. 277527 (1976, 1977).

11) Von. S. Pollman: V.G.B., 94, 7 (1965).

12) G. W. Cuningham \& A. deS Brasunas: Corrosion, 12, 389 (1956).

13) A. J. B. Cutler and C. J. Grant: Corrosion of Iron and Nickel Base Alloys in Alkal Sulphate Metals, p. 591, The Electrochemical Society, Princeton, N. J., USA (1975).

14) K. H. Stern \& E. L. Weise: NSRDS-NBS 7, p. 27 (1966).

15) P. H. Effertz \& D. Wiume: 機械の損害, 2, p. 49 (1980).

16）宮川大海：日本金属学会会報，13, No. $12 ， 882$ (1974).

17) A. J. B. Culter \& T. Flatley et al.: CEGB Research, Oct (1978).

18）根本力男：日本金属学会会報，18，No. 3，192 (1979). 